\title{
Family Farming and Biodiesel: The Difficulties of Socioeconomic Inclusion in the Northeast of Brazil
}

\author{
Marcelo Santana Silva ${ }^{1,2}$, Francisco Lima Cruz Teixeira ${ }^{2}$, Ednildo Andrade Torres ${ }^{2}$, Fábio Matos Fernandes ${ }^{3} \&$ \\ Angela Machado Rocha ${ }^{2}$ \\ ${ }^{1}$ Department of Energy, Federal Institute of Bahia (IFBA), Santo Amaro, Bahia, Brazil \\ ${ }^{2}$ Interdisciplinary Center for Energy and Environment (CIEnAm), Federal University of Bahia (UFBA), Brazil \\ ${ }^{3}$ State University of Bahia (UNEB), Brazil \\ Correspondence: Marcelo Santana Silva, Interdisciplinary Center for Energy and Environment (CIEnAm), \\ Federal University of Bahia (UFBA), Brazil. Tel: 55-713-283-9808. E-mail: marcelosilva@ifba.edu.br
}

Received: April 18, 2014 Accepted: May 27, 2014 Online Published: June 15, 2014

doi:10.5539/jas.v6n7p231 URL: http://dx.doi.org/10.5539/jas.v6n7p231

\begin{abstract}
The "National Program for Production and Use of Biodiesel in Brazil" (PNPB) in Brazil was formulated with the objective of promoting the rural development, especially in the Northeast and semiarid region and impacting positively on the environmental issue. Therefore, the aim of this study is analyzing the scenario of the inclusion of family farming and the biodiesel market in the Northeast and in Bahia, as well as highlighting the main obstacles of this biofuel in areas covered by the study. This work is characterized as qualitative and exploratory, whose technical procedures adopted were the bibliographic research and the fieldwork. The research indicated that what was idealized for the biodiesel market in the northeast and in Bahia does not happen as planned. In addition, besides the economic and environmental justification for the introduction of biodiesel into the Brazilian energy matrix, the social issue with poverty reduction in marginal areas of the country has been much valued by the program. However, the PNPB has failed in the Northeast region of Brazil, despite government efforts. As such, it was verified the existence of several barriers that have impacted and remain obstructing the biodiesel market in the region and in the researched State.
\end{abstract}

Keywords: biodiesel, familiar agriculture, inclusion, Northeast, Brazil

\section{Introduction}

The world population has been increasing in an accelerated rate. According to projections by United Nations (UN), the world will house 10 billion inhabitants by the year 2075 (UN, 2011). The increase in population poses major socioeconomic challenges with guaranteed access to essential goods and services for survival and improved quality of life of people, requiring intensive use of natural resources, especially fossil fuels to sustain the comforts of modern society with regard to transportation, electricity and heat.

In 2010, those fuels provisioned approximately $81 \%$ of all primary energy utilized in the world (IEA, 2012). Therefore, the search for other resources of energy that will lead to a reduced use of fossil fuels has become a major policy challenge for the achievement of sustainable development (GREENPEACE, 2010; Hertel, 2013; Goldemberg et al., 2014).

Among the renewable energy sources, stand out biofuels derived from biomass, organic matter in an ecosystem or in a plant or animal population (Torres et al., 2006; Wilkinson \& Herrera, 2010; Silva Júnior, 2013).

There are different types of biofuels, such as biodiesel that, in chemical terms, is a mixture of alkyl esters of fatty acids and can be produced from oils extracted from plants, residual grease or animal fats (Dermibas, 2009; Pereira et al., 2012; Bergmann et al., 2013).

Although Brazil has a long experience in the field of agroenergy, as researches conducted for the use of vegetable oils as fuel by the National Institute of Technology in 1929; of the programs National Alcohol Program (Proalcohol), Brazilian Program of Aeronautical Vegetal Kerosene (Prosene), Program Vegetable Oils (Prooil) and the Program of Palm Oil (DenDiesel) in the 1970s and 1980s. Only in the second half of the 2000s, an inter-ministerial program, denominated National Program for Production and Use of Biodiesel (PNPB), was 
implemented by the Brazilian government for sustainable inclusion - technically and economically - of biodiesel in the national energy matrix (MCT, 2005).

In addition to inserting the biodiesel into the Brazilian energy matrix, the Law 11.907 of January 13, 2005 that regulates the PNPB, clearly says that familiar agriculture must be included in the program (Brasil; Casa Civil 2005), thus ensuring the opening of jobs, the improvement of income and the promotion of economic and social development in poor and marginal areas for agricultural production, such as the Brazilian Northeastern Region (FGV, 2010; MDA, 2011).

After eight years since the release of PNPB, the biodiesel market in Brazil (production and consumption) has widened significantly, ceasing to be almost non-existent to be among the largest ones in the world (Renewable Energy Policy Network, 2013). The program has also boosted the number of private investments in the industrial sector in almost all over Brazil (Goncalves et al., 2013). However, the PNPB has failed in the Northeast of Brazil, despite the government efforts (Santos \& Rathmann, 2009; Leite et al., 2013; Diniz \& Favareto, 2012; César \& Batalha, 2013; César et al., 2013).

In the current scenario, among the nine states that form the Northeastern Region in Brazil, four have power plants enabled and accredited for biodiesel commercialization, but only in Bahia and Ceará there are power plants producing biodiesel. Those states are responsible for around $10 \%$ of the volume of national production, however, despite this volume, there is a deficit of $163,110 \mathrm{~m}^{3}$ of biodiesel detected to meet the mixing of $9,133,665 \mathrm{~m}^{3}$ diesel oil consumed in the region in 2012 (ANP, 2013).

The Brazilian northeast region presents a high level of anthropization, as a result of secular agro pastoral practices and the inappropriate use of natural resources. This region has a strong tradition linked to the familiar agriculture and a great diversity of vegetation, soil and climate. However, there is a limited availability of water, low rates of Human Development Index (IDH) in the country and a low land cost (EMBRAPA, 2013).

Moreover, the geo-environmental conditions, with different types of climates, rain systems, soils and hydrography, reliefs, associated to a reasonable transportation infrastructure, make the region attractive for the production of several kinds of oilseeds designated for the biodiesel production (Vaccaro et al., 2010; Padula et al., 2012).

Cultures as castor oil, palm oil, jatropha, peanut, cotton, soybean and sunflower are suitable for planting inlands of difficult utilization and/or already degraded by conventional agriculture (Nogueira, 2011).

Some of these cultures are already part of the day-to-day family farmer in the Brazilian northeast, which already has the tradition of cultivate them in consortium with other species for subsistence and/or focused on the domestic market, such as corn and beans that compose the nutritional basic food basket of the Brazilians.

The northeast region holds about $50 \%$ of the number of Brazilian family farmers and the State of Bahia registers $30 \%$ of the number of farmers from this region (França, Del Grossi, \& Marques, 2009; IBGE, 2010).

Another problem detected in the northeast of Brazil regards the mismatch among the number of farmers inserted into the PNPB, the acquisitions of raw materials from biodiesel producers, the income obtained by the households and the number of cooperatives linked to the program that operates in the region.

Given this context, linked between the biodiesel production and the importance of the familiar agriculture, an analysis of the results in the State of Bahia was made, as a result of its leadership on this field in the northeast region.

The aim of this work is analyzing the scenario of inclusion of the familiar agriculture and the biodiesel market in the northeast of Brazil, in particular the State of Bahia. Therefore, the purpose of this article is to provide an analysis of the results of PNPB over the recent years, highlighting the main barriers in the area covered by the study.

This article has been structured in six sections. Besides the introductory section, the methodology, the familiar agriculture issue and the PNPB, the biodiesel market in Brazil, the status of the program in the northeast region and in the State of Bahia and, finally, the barriers of the program in these regions will be presented and discussed below.

\section{Methodology}

The research is a formal procedure, with a method of reflective thinking, which requires a scientific treatment and it is on track to meet the reality or to find partial truths (Marconi \& Lakatos, 2008). Therefore, in order to establish the best methodological path that led to the expected results, this study has adopted the methodological approach 
proposed by Gil (2009), who considers how to approach the problem, the objectives and the technical procedures adopted.

Regarding the way to approach the problem, this research is characterized by qualitative to be possible to understand the context of the situation studied, enabling the capture and interpretation of phenomena and assign meanings to these (Marconi \& Lakatos, 2008). The qualitative research is part of larger issues for understanding the phenomena that take shape as work progresses, which requires the consultation on different sources for data collection (Gil, 2009).

Regarding the objective raised in this article, this research is exploratory due to allowing an increasing familiarity with the problem raised (make it explicit) and to be more flexible and informal, allowing researchers to seek more knowledge on the subject in perspective (Gil, 2009).

The technical procedures adopted in the researches classified as qualitative and exploratory are broad and versatile (Marconi \& Lakatos, 2008). In this article, the bibliographic and documentary surveys were utilized, as well as the realization of semi-structured interviews with experts and scholars from the biodiesel production chain.

The data collections were carried out in December 2012 and August 2013 in two major international events of biodiesel in Brazil.

The categories were: (I) Regulatory Barriers and Public Policies; (II) Economic Barriers; (III) Agronomic Barriers; and (IV) Technological and Infrastructural Barriers.

28 experts were interviewed, in order to include the different agents that work on the chain, such as: Companies (11), public sector (10), associations and syndicates (8), researchers (4). The information obtained was triangulated, enabling the understanding and explanation of the problem studied.

After tabulating the data, the information obtained was triangulated, enabling the understanding and explanation of the problem studied.

\section{Familiar Agriculture and PNPB in the Northeast}

Besides the economic justification for the introduction of biodiesel into the Brazilian energy matrix, the social issue with the reduction of poverty in marginal areas of the country has been much valued by the Brazilian government. The adopted strategy was inserting compulsorily familiar agriculture in the biodiesel productive chain. Thus, it becomes important to understand the universe of familiar agriculture in Brazil before tackling its insertion into the PNPB.

\subsection{Familiar Agriculture}

In the Brazilian agrarian universe, there are different kinds of farmers with their own interests and strategies of organization and production, which make them responding differently to the challenges imposed by the market.

There are peasants, settlers, planters, small producers, farmer-settlers and others. These various denominations for food producers were unified under the concept of family farmers, in contrast to the employer agriculture (Lamarche, 1993; Altafin, 2012).

From a legal perspective, the concept adopted in this article for the familiar agriculture is described in the Law number 11.326 of 24th July 2006, establishing guidelines for the formulation of the national policy of familiar agriculture and rural family enterprises, classifying the farmers from the basic conditions of the production process for financing purposes. In its Article 3, the law considers that:

"Family farmer and rural farmer entrepreneur is one who practices activities in the rural areas, meeting, simultaneously, the following requirements: (I) does not hold, in any capacity, an area larger than 4 (four) fiscal modules (Note 1); (II) utilize mostly the hand laborof the family itself in the economic activities of its establishment or undertaking; (III)has family income predominantly originated by economic activities related to the establishment itself or undertaking; (IV) manage his/her establishment or undertaking with his/her family" (Brasil; Casa Civil, 2006).

The familiar agriculture is, therefore, composed of small and medium rural properties, settlements, of agrarian reform and traditional rural communities, such as foresters, extractivists, riparians, quilombolas, aqua culturists, among others, as long as they meet the requirements in the Law.

It ranges from establishments managed by poor families with low educational level and utilizing antiquated methods of production and low productivity, to establishments with a high level of organization, with access to technology (machinery, improved seeds, fertilizers, soil correction etc.), infrastructure and occasionally linked to the agroindustry (Buainain, Guanziroli, \& Sabbato, 2004). 
Due to this multiplicity, different typologies are used to classify and differentiate the familiar farmers themselves. In this article, it has been adopted the classification of the report New Portrait of Familiar Agriculture: the rediscovered Brazil, a technical cooperation project INCRA/FAO, coordinated by Guanziroli and Cardim (2000). The researchers have established five categories of family farmers when considering the different degrees of socioeconomic development, level of capitalization and income generation, as shown in the Table 1.

Thus, it was possible to capture several aspects of productive activity, such as the insertion in the market, transformation and processing of agricultural products within the establishment and on-farm consumption.

Table 1. Category of family farmers

\begin{tabular}{ll}
\hline Category & \multicolumn{1}{c}{ Description } \\
\hline Type A & $\begin{array}{l}\text { Family farming with a certain economic stability, with strong commercial insertion and associated to } \\
\text { the cooperatives. They apply high technology, because they utilize modern inputs and the properties } \\
\text { are intensively mechanized. Predominated in the Brazilian Cerrado region. }\end{array}$ \\
Type B & $\begin{array}{l}\text { Family farming integrated vertically with the Agro industrial Complexes. It is called integrator } \\
\text { peasant-agroindustry complex, due to it has the capacity to adopt technological innovations required } \\
\text { by the agroindustry, with the aim of homogenizing the raw materials acquired for the productive } \\
\text { process of the processing plant. }\end{array}$ \\
Type C & $\begin{array}{l}\text { Family farming typically colonial with great rural tradition. The rural establishments are linked to the } \\
\text { polyculture, combining tillage, orchards with the livestock and the raising of small animals for family } \\
\text { consumption itself. It is not integrated to the agroindustry. }\end{array}$ \\
Type D & $\begin{array}{l}\text { Semi-commercial family farming, where most of the production is destined to the on-farm } \\
\text { consumption. It has a low capital level and predominates in the Northeast, the Midwest and the South. }\end{array}$ \\
Type E & $\begin{array}{l}\text { With similar origin to the type D, although without perspectives and marginalized in the economic } \\
\text { process. }\end{array}$
\end{tabular}

Source: Adapted from Guanziroli and Cardim (2000).

Besides the different types of family farmers, it is noteworthy that in the five Brazilian regions, the agriculture performed by them also presents different characteristics, such as in the South region, where it is more dynamic than the Northeast region. This is due to the agrarian pattern adopted by the European immigrants, especially the Germans and Italians, who reproduced the same production system of the country of origin - mechanized and diversified, while most family farmers in the Northeast region work with a low level of agricultural modernization, producing mostly for subsistence (Buainain, Guanziroli, \& Sabbato, 2004).

Based on the results of the 2006 Agricultural Census, conducted by the Brazilian Institute of Geography and Statistics (IBGE), França, Del Grossi and Marques (2009) performed a study for the MDA, titled "Family Farming in Brazil and the 2006 Agricultural Census", where it was possible to know the profile of these farmers in Brazil. The most relevant findings are discussed below.

In Brazil, Family farming has 4,367,902 establishments, representing $84.4 \%$ of the total. The Northeast region houses around $50 \%$ of these establishments, totalizing 2,187,295 units and Bahia, with 665,831 establishments, is the State with the largest number of rural properties, representing $15.2 \%$ of the national total and $30 \%$ of the Northeast region (França, Del Grossi, \& Marques, 2009).

Regarding the area occupied by the Brazilian agricultural establishments, only $24.3 \%$ of the total or about 80.25 million hectares are from family farmers, demonstrating a concentrated agrarian structure in the country. Bahia, with 9,955,563 ha (12\%), occupies the largest area with family farming establishments among the Federal Units. Concerning the average size of family farming establishments, it represents 18.37 ha, while the non-family farmers represent 309.18 ha (IBGE, 2010).

Regarding land use, $45 \%$ of $80,250,453$ ha used for family farming are pastures, $22 \%$ are tillage and $24 \%$ are areas with woods, forests or agroforestry systems. With regard to tillage, despite cultivating a smaller area, family farming is an important food supplier for the domestic market, producing, for example, about $70 \%$ of the bean production, $46 \%$ of corn, $38 \%$ of coffee, $34 \%$ of rice and $16 \%$ of soybeans. The Gross Value of Production (GVP) (Note 2) generated by the family farming is 54 billion dollars, or something around $38 \%$ (França, Del Grossi, \& Marques, 2009). 
Considering occupation, the family farming employs almost four times more people than the non-family farming. It represents 12.3 million people, corresponding to $74.4 \%$ of the workforce employed. Regarding the non-family farming, it employs 4.2 million people or $25.6 \%$. For every 100 hectares, 15.3 people are employed in family farming, while family farming represents 1.7 people (França, Del Grossi, \& Marques, 2009; IBGE, 2010).

Based on the figures presented, there is the dimension of the importance of family farming to Brazil and the federal government interest to insert it into the biodiesel productive chain. However, difficulties have arisen throughout the program since many farmers, especially those in the Northeast region, had never participated in an agro industrial productive chain. Moreover, the size of their properties and multifaceted character of its product mix has become a limiting factor due to the production chain of biodiesel requires large extensions of land and use of sophisticated technologies to ensure scale and production efficiency (Abramovay \& Magalhães, 2007).

\subsection{Participation of the family farming of Northeast Region in the PNPB}

To facilitate the insertion of the family farmers in the biodiesel program, the Brazilian government has created instruments such as the Social Fuel Stamp (SFS), the Project Poles of Biodiesel and the commercialization system via auctions.

The SFS is an identification granted to the biodiesel producer, conferring him the status of social inclusion promoter of family farmers framed in the National Program for Strengthening Family Farming (PRONAF), by enabling them to participate in the national fuel market, providing raw materials for the production of biodiesel. In contrast, the biodiesel producer gets reduced rates of federal taxes - PIS/PASEP e COFINS (BRASIL, 2004; Castro, 2011).

Among the advantages of the SCS are: decreased rates of federal taxes and the Social Integration Program Training Program the Public Service (PIS / PASEP) as well as the Contribution to Social Security Financing (COFINS), varying according to the raw materials purchased and region; commercial financing and incentives; and ensuring participation in larger batches of auctions organized by the Brazilian National Agency of Petroleum, Natural Gas and Biofuels (ANP), which joins biodiesel producers, refiners and distributors, who buy this biofuel blend it with diesel fuel oil.

Regarding the Project Poles of Biodiesel, created in 2006, it was the main strategy for the operationalization of the PNPB in a micro-regional or territorial level. It aimed to promote and facilitate the organization of the productive base of oilseeds and facilitate the insertion of family farming in the program, as well as provide access to the public policies, transference of knowledge and technology and adequate training (2008). In 2010, there were 63 poles involving 1,091 municipalities scattered throughout the country. The Northeast housed around $51 \%$ of the poles and $43 \%$ of the municipalities, totaling 32 poles and 462 municipalities. Of this total, 9 (nine) poles are situated in the State of Bahia (MDA, 2011).

The high percentage of poles set in the Northeast is justified by the greater need to organize the productive bases for the oilseeds cultivation, since most family farmers are classified as types D and E, according to the classification proposed by Guanziroli and Cardim (2000).

The plants with the Social Fuel Stamp (SFS) may participate in the auction sale of biodiesel. The plants that have the stamp may participate in $80 \%$ of the volume to be negotiated in the auction and $20 \%$ may also participate the plants that don't possess the SFS.

The commercialization of biodiesel is performed through auction sponsored and supervised by the National Regulatory Agency for Oil, Natural Gas and Biofuel (ANP), among the producer, refiner and distributor. One of the purposes of biodiesel auctions is to ensure the sale of the product produced by the plants in an extremely competitive market, reducing the risk and, consequently, providing a reduction in final prices for the respective consumers of the product (Watanabe et al., 2012).

These stimulus policies have impacted positively on the number of establishments in the family farming inserted in PNPB between 2005 and 2012. However, they are below the intended purpose of the Federal Government, who expected to insert in the program about 200 thousand family farmers in the early years -2005 to 2008 (REPORTER BRASIL, 2010).

In the Figure 1, it is observed that from 2008, the number of family farming establishments that joined PNPB has shown a strong increase, reaching 104,295 establishments in 2011. However, a reduction of $11.14 \%$ was registered between 2011 and 2012, reaching 92,673 establishments (Machado, 2012; Rodrigues, 2012). 


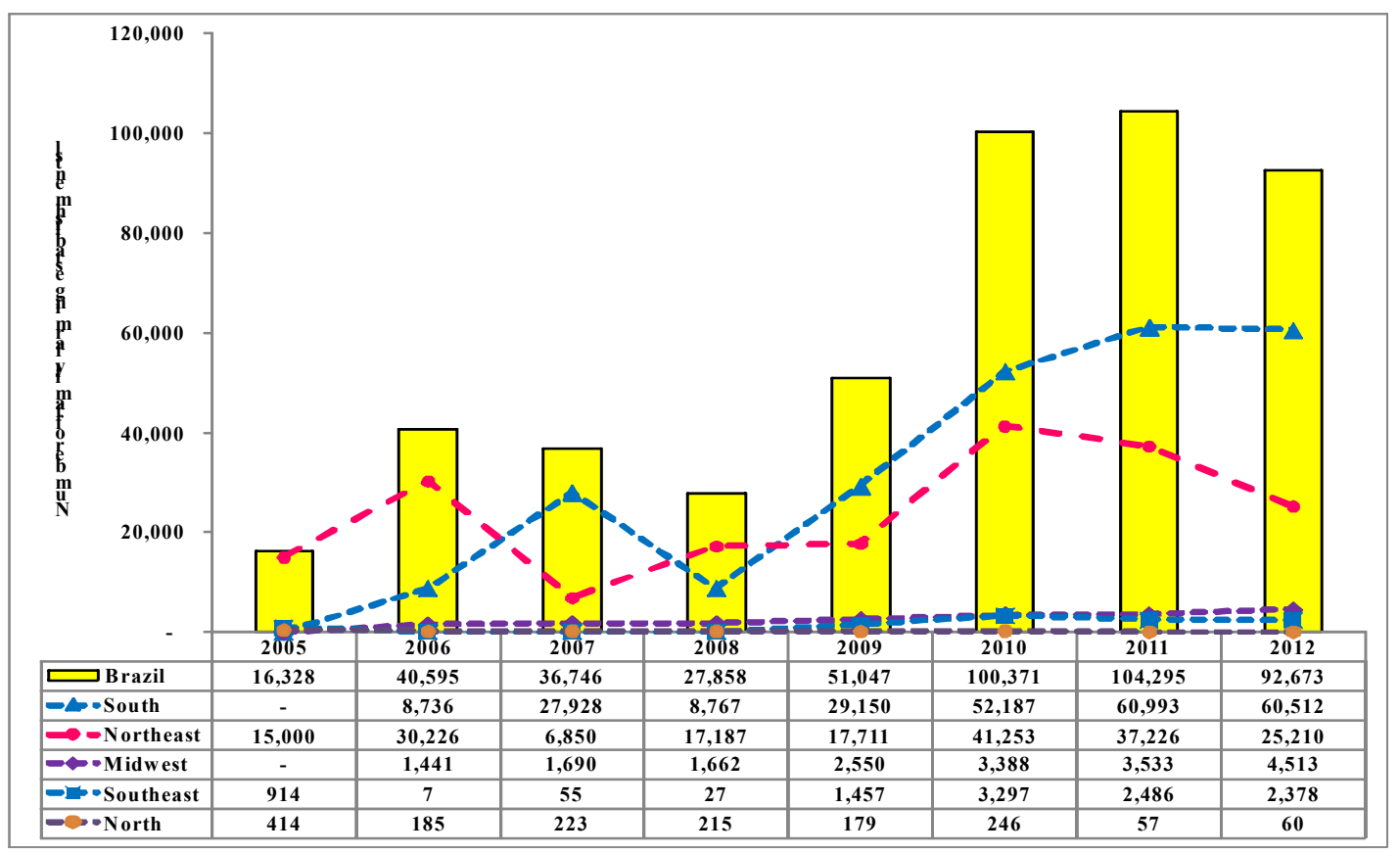

Figure1. Evolution of the number of family farming establishments, participants of PNPB by region in Brazil, from 2005 to 2012

Source: Own elaboration based on: Machado (2012) and Rodrigues (2012).

Regarding the Northeast, after a fall of more than $75 \%$ over the number of family farming establishments that joined the PNPB between 2006 and 2007, a revival was recorded from 2008, reaching 2010 with the participation of $41.10 \%$ of the total national establishments. However, the crop failure occurred due to the drought in 2011 and 2012 caused a retreat of $61.11 \%$ of family farmers in the region, representing 25,210 in 2012, (Rodrigues, 2012), corresponding to $27.20 \%$ of the national total. The Figure 2 shows the percentage distribution in the number of family farming establishments that joined the PNPB in 2012.

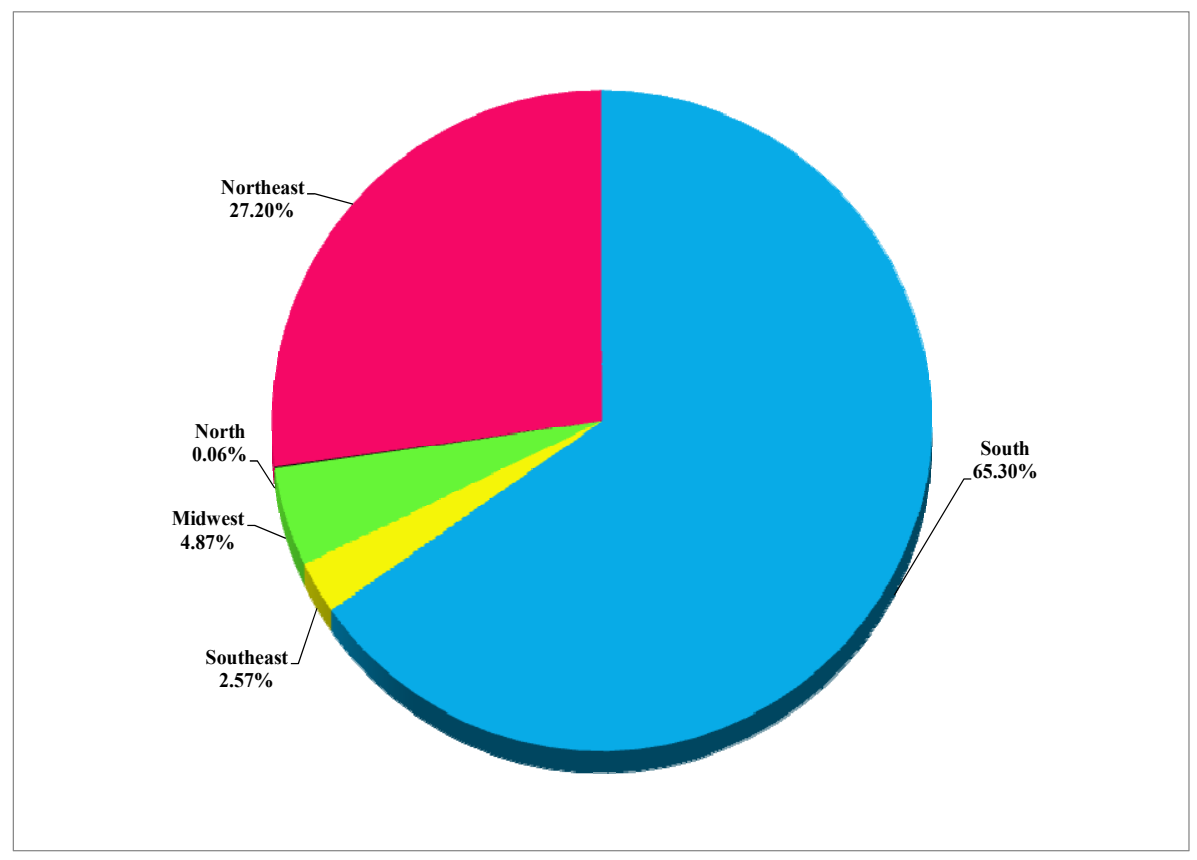

Figure 2. Percentage distribution in the number of family farming establishments that joined the PNPB in 2012 Source: Own elaboration based on: Machado (2012), Rodrigues (2012) and MDA (2011). 
Regarding the total volume of raw materials acquisitions of family farming to the biodiesel production, it was observed a growth rate of $664.64 \%$ between 2008 and 2012, representing, in monetary terms, more than 6.4 billion of accumulated reais (Figure 3).

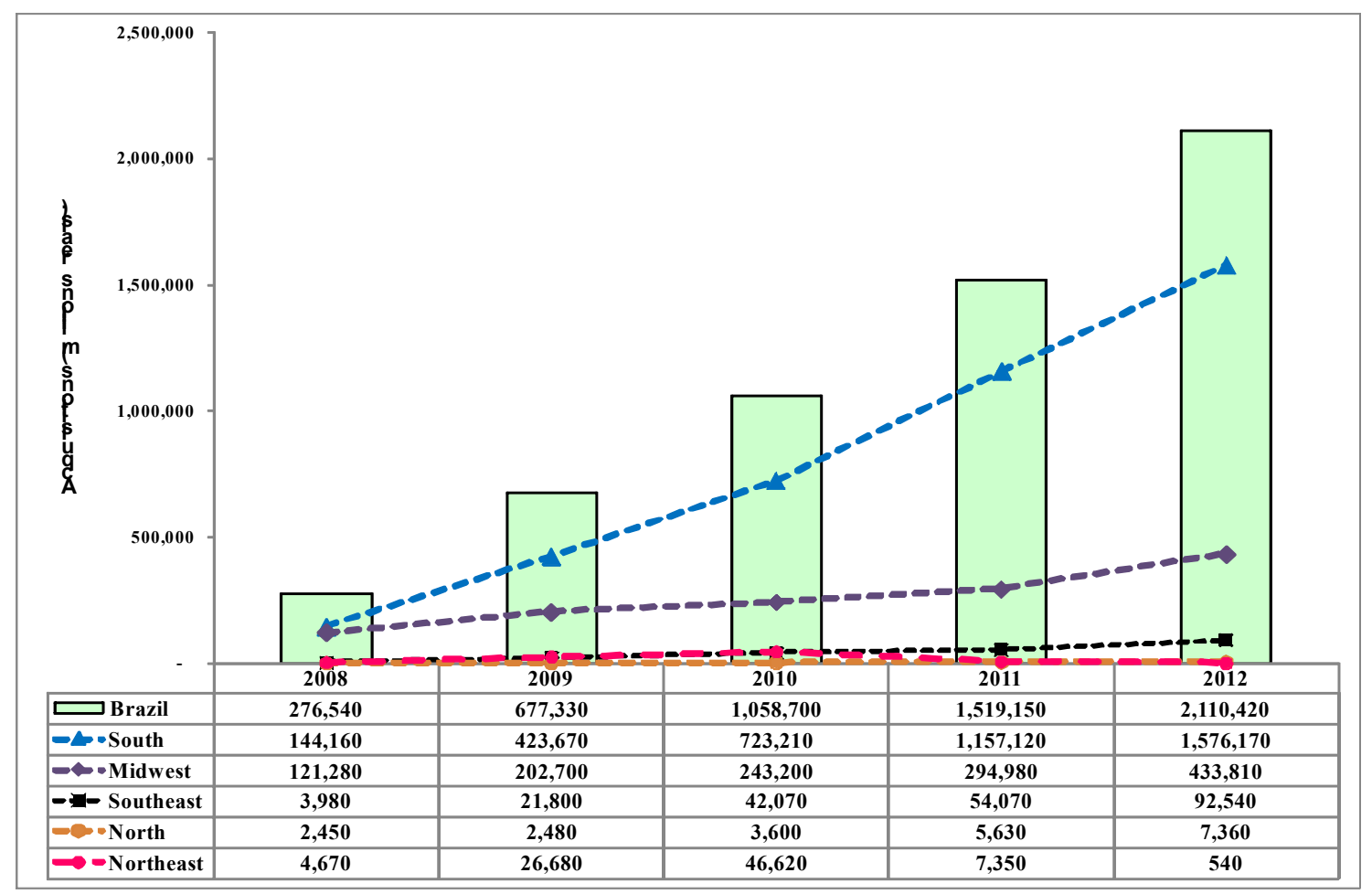

Figure 3. Acquisitions of raw materials from family farming by region in Brazil, from 2005 to 2012 (millions reais) Source: Own elaboration based on: Machado (2012), Rodrigues (2012) and MDA (2011).

It is noteworthy that in this period, the South and Midwest regions provided more than $90 \%$ of the total acquired. A combination of factors contributed to such disparity, as the high number of family farming establishments, the cooperative organization and the field of soybeans as the main crop in the South. In the Midwest region, it is highlighted the average area allowed for family farming, which affects the production volume and the soybean prevalence (MDA, 2011).

Although sheltering the largest number of family farmers among the Brazilian regions, the Northeast presented its best performance in the volume of acquisitions of raw materials in 2010 , when provided $4.44 \%$ of the total, presenting once again a strong decrease in 2011 and 2012.

In this last year, only $0.03 \%$ of the total acquisitions came from this region, despite having received approximately $43 \%$ of all the investment in technical assistance, $22 \%$ of all input donations performed by the companies that produce biodiesel and employ nearly $33 \%$ of the agricultural technicians involved with the program (Machado, 2012).

The upward trend observed in the acquisitions curve must continue in the upcoming years, which shows that there is an income transfer to the family farmers. However, this reality is not applicable to the Northeast region, where the gross income per family by selling raw materials was $\mathrm{R} \$ 21.42$ per year or $\mathrm{R} \$ 1.79$ per month (MDA, 2013), leading many farmers to abandon the PNPB (Figure 4). 


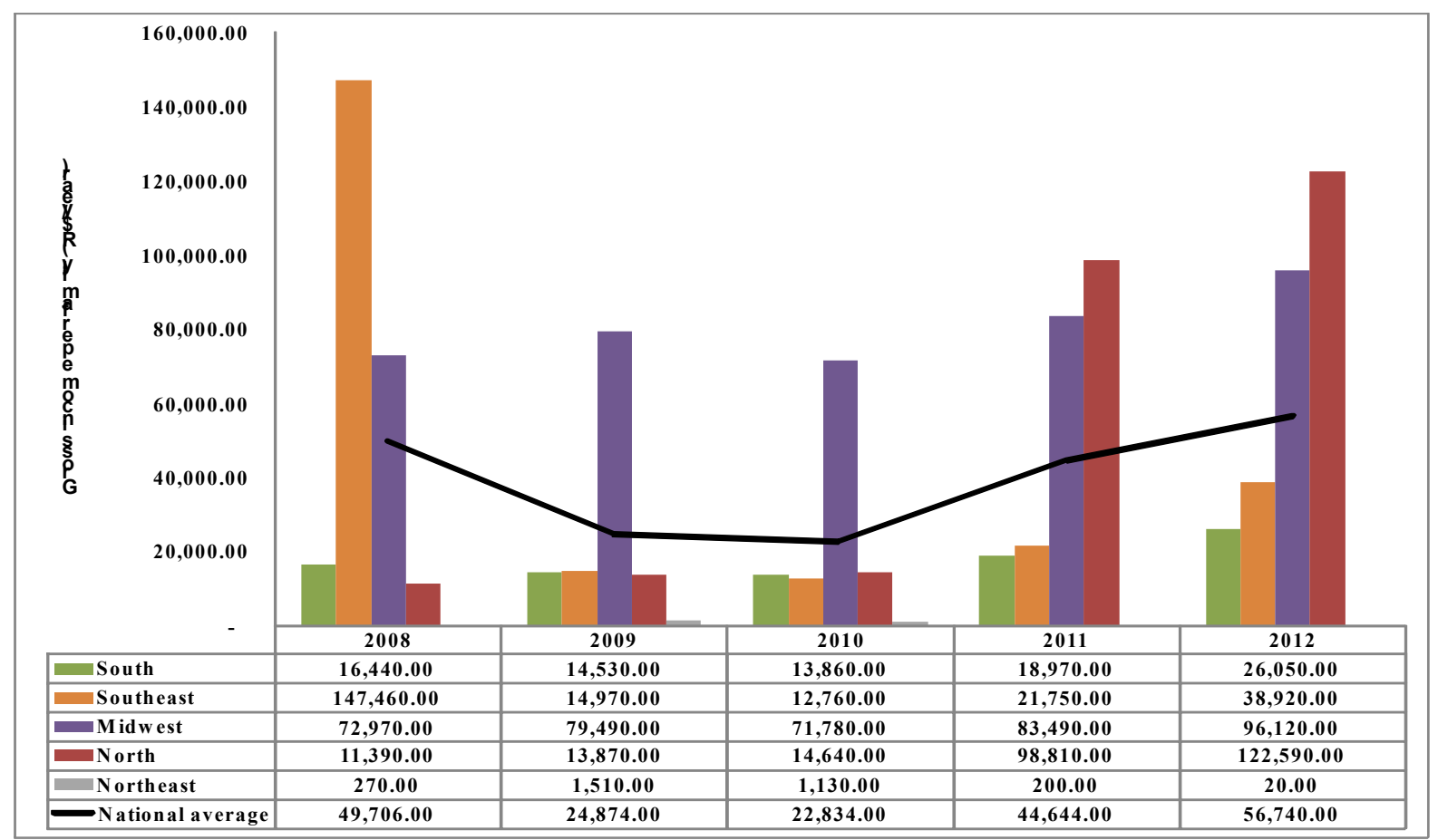

Figure 4. Gross income per family (R\$year)

Source: Own elaboration based on: Machado (2012), Rodrigues (2012) and MDA (2011).

Among the possible causes for the low volume of acquisition of raw materials for biodiesel in the Northeast region, Perez (2012) points out: (i) low productivity, related to climatic factors, use of deficient rudimentary technologies and the inexperience of the family farmer in producing oilseeds; (ii) poor logistics infrastructure; (iii) deficient technical assistance, (iv) spatial dispersion of family farmers; and (v) low productive organization of family farmers.

Based on the presented data, it can be stated that the PNPB does not fulfill its objective in the Northeast region, with the opening of jobs, the improvement of income and the promotion of the economic and social development.

\section{The Biodiesel Market in Brazil}

The industrial park for the biodiesel production in Brazil has grown in an accelerated pace. In 2005, beginning of the implementation of PNPB, there were only 8 power plants with installed capacity for $64 \mathrm{mil} \mathrm{m}^{3} / \mathrm{ano}$ (IPEA, 2012). In September 2013, the number of power plants authorized to produce and commercialize biodiesel through auctions reached 60 , with the installed capacity of production of 7,532 thousand of $^{3} / \mathrm{year}$, as illustrated in the Figure 5 below, with almost $87 \%$ of this capacity belonging to power plants holders of the Social Fuel Stamp (SFS) (Note 3), which represents a volume in production of 6,553 $\mathrm{m}^{3} / \mathrm{year}$ (MME, 2013). 


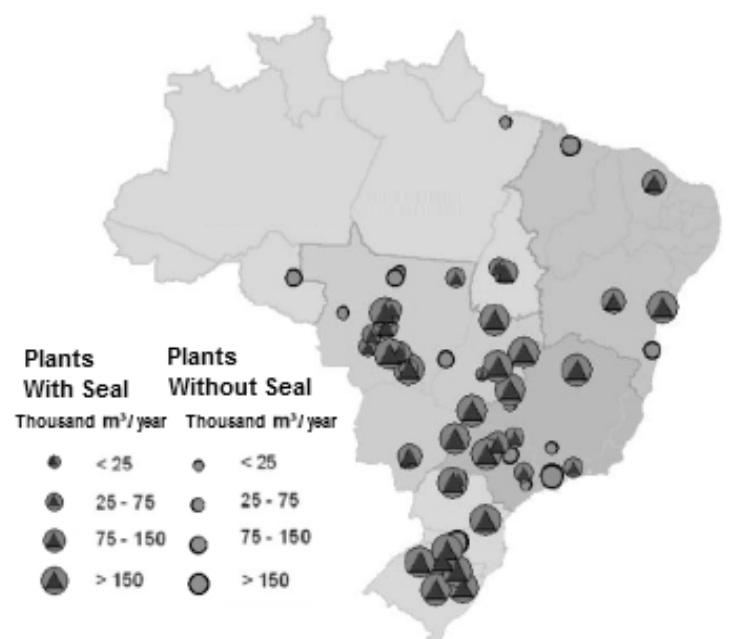

\begin{tabular}{|c|c|c|c|}
\hline \multirow{2}{*}{ Region } & \multirow{2}{*}{$\begin{array}{c}\mathbf{N}^{\mathbf{0}} \\
\text { plants }\end{array}$} & \multicolumn{2}{|c|}{ Installed Capacity } \\
\cline { 3 - 4 } & & $\begin{array}{c}\text { Thoussand } \\
\mathbf{m}^{\mathbf{3}} / \mathbf{y e a r}\end{array}$ & $\mathbf{\%}$ \\
\hline North & 4 & 202 & $3 \%$ \\
\hline Northeast & 5 & 706 & $9 \%$ \\
\hline Midwest & 28 & 3,288 & $44 \%$ \\
\hline Southeast & 11 & 890 & $12 \%$ \\
\hline South & 12 & 2,446 & $32 \%$ \\
\hline
\end{tabular}

Figure 5. Localization of the biodiesel power plants in Brazil

Source: MME (2013).

The expectation is an increase in the number of power plants and, consequently, the capacity for the next years to come with the permission to build two new plants and expansion of other 5 (ANP, 2013) (Note 4).

However, there is evidence that large national and international corporations have dominated the field, due to only in 2011 a group of 20 plants was responsible for $96.6 \%$ of the biodiesel produced, as shown in the Table 2 below (IPEA, 2012).

Table 2. Participation of the Biodiesel production plants by group size

\begin{tabular}{cccc}
\hline \multirow{2}{*}{ Reference Year } & \multicolumn{3}{c}{ Production $\left(\mathrm{m}^{3}\right)$ by group of companies } \\
\cline { 2 - 4 } & The biggest5 in \% & The biggest10 in \% & The biggest20 in \% \\
\hline 2008 & 61.2 & 88.8 & 99.8 \\
2009 & 53.4 & 82.5 & 97.8 \\
2010 & 49.5 & 79.3 & 96.6 \\
2011 & 47.6 & 74.5 & 96.6 \\
Average & 47.3 & 70.7 & 94.9
\end{tabular}

Source: Own elaboration based on: IPEA (2012).

Regarding the installed capacity of power plants, currently it is superior to the need of demand, leading to idleness industry to be around $60 \%$, with final data of 2012, as illustrated in the Figure 6 below, which may worsen with authorizations for construction of new plants, as well as with the increased capacity of the plants that are in operation (MME, 2013; ANP, 2013). 


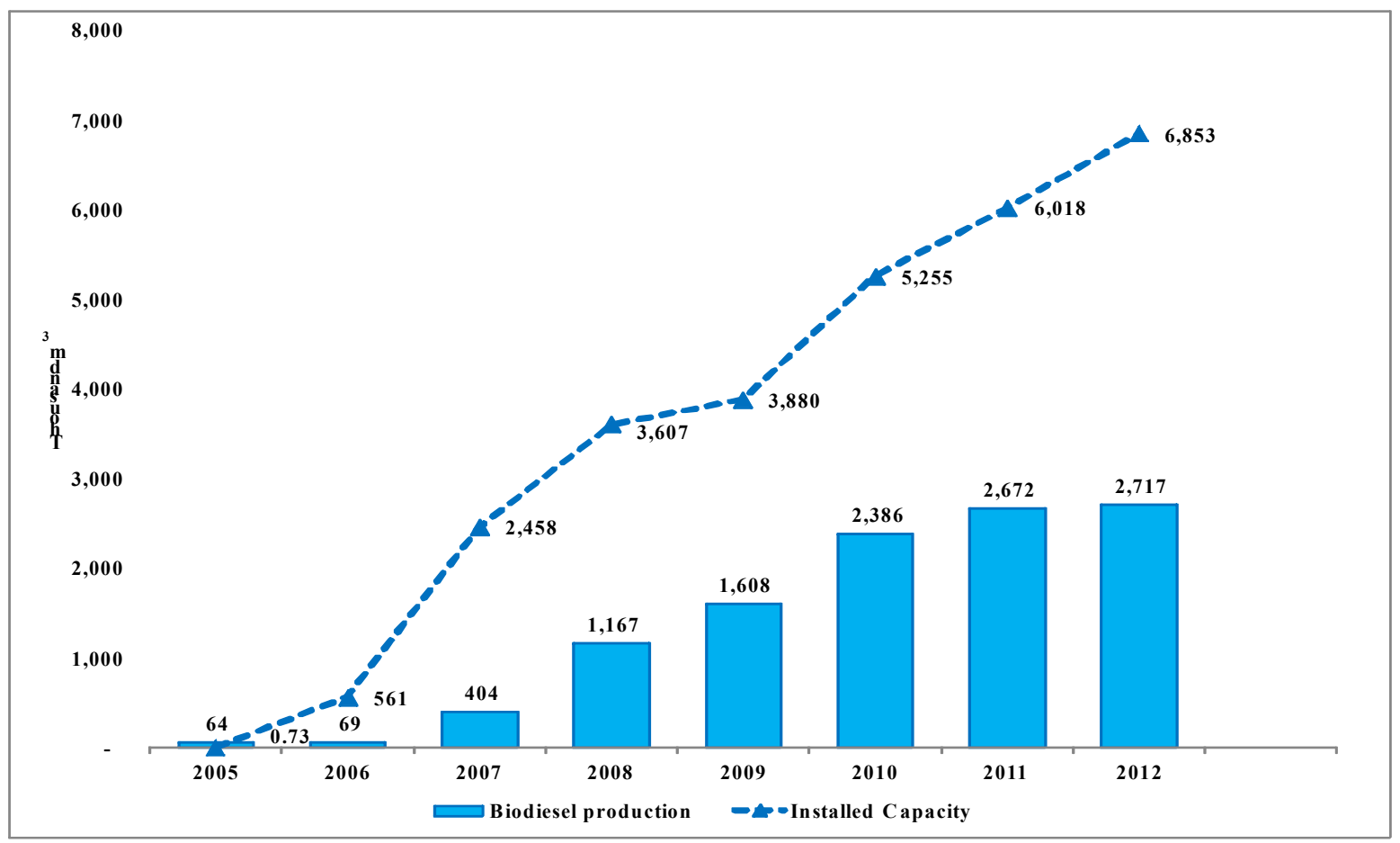

Figure 6. Production and installed capacity of biodiesel production in Brazil

Source: Own elaboration based on: MME (2013).

In 2012, the domestic biodiesel production was about 2.72 billion liters to meet the mandatory blending from biodiesel to diesel, which currently is in B5, or 5\% biodiesel blended with mineral diesel (ANP, 2013). Until the cumulative year, October 2013, the production reached 2.16 million $\mathrm{m}^{3}$, an increase of $9 \%$ over the same period of 2012 (MME, 2013).

The regional production, data from September 2013, showed the following distribution: $43.9 \%$ (South), 37.3\% (Midwest), 8.8\% (Northeast), 7.9\% (Southeast) and 2\% (North) (MME, 2013).

It was observed that from 2005 to 2012 there was an increase in the biodiesel, due to mandatory regulations imposed in the country. For the last three years (2010-2012), the average was 2.5 billion liters / year, considering that this expansion of industrial production was more expressive and in its first five years.

Given this situation, the authorization of the mixture to increase until B5 was a consequence of the response of the business community and an increased industrial capacity, being secondary to the environmental and social issues.

As the demand of B5 is on average two and a half billion liters of biodiesel, in theory there are no threats of shortages in a short-term horizon, on the contrary, there is an excess of capacity, but with a high vacancy rate, hovering around $60 \%$ in the required periods for addition of biodiesel from 2008 to 2012 (MME, 2013).

On the other side, it was recorded a low level of use of biodiesel plants, with an average of $40.85 \%$ of their installed capacity on average in the period 2008-2012 (Table 3 below). It is important to highlight that this index reflects a rather heterogeneous reality in this industry, because there are companies using almost all of its production capacity and other companies presenting other indexes below $20 \%$, which proved that the program needs to be revised and refined throughout its bond in the production chain (MME, 2013).

$88 \%$ of the plants are located in the central-west, south and southeast regions. Their production is distributed as follows: $44 \%, 32 \%, 12 \%$, respectively, as of September 2013. It is noteworthy that the largest biodiesel producing states are located in the agro industrial complex of soy, which are: Rio Grande do Sul, Goiás, Mato Grosso and São Paulo, accounting for about 70\% of national production in 2012 (MME, 2013). 
Table 3. Production, Installed, Idle and Utilized Capacity from 2005 to 2012 (thousand $\mathrm{m}^{3}$ )

\begin{tabular}{ccccccc}
\hline Year & Production & $\begin{array}{c}\text { Installed } \\
\text { Capacity } \\
\text { (B) }\end{array}$ & $\begin{array}{c}\text { Idle } \\
\text { Capacity } \\
(\text { C=B-A) }\end{array}$ & $\begin{array}{c}\text { Idle } \\
\text { Capacity } \\
(\%)\end{array}$ & $\begin{array}{c}\text { Utilized } \\
\text { Capacity } \\
(\%)\end{array}$ & $\begin{array}{c}\text { Average Utilized } \\
\text { Capacity } \\
(\%)\end{array}$ \\
\hline 2005 & 0.7 & 64 & 63.3 & 98.90 & 1.10 & \\
2006 & 69 & 561 & 492 & 87.70 & 12.30 & \\
2007 & 404 & 2,458 & 2,054 & 83.56 & 16.44 & \\
\hline 2008 & 1,167 & 3,607 & 2,440 & 67.65 & 32.35 & \\
2009 & 1,608 & 3,880 & 2,272 & 58.56 & 41.44 & \\
2010 & 2,387 & 5,255 & 2,868 & 54.58 & 45.42 & \\
2011 & 2,673 & 6,018 & 3,345 & 55.59 & 44.41 & \\
2012 & 2,717 & 6,853 & 4,136 & 60.36 & 39.64 & \\
\hline
\end{tabular}

Source: Own elaboration from MME data (2013).

With regard to region of the Midwest, in addition to having the largest installed capacity of the industrial production of biodiesel, it has, at the same time, exported soybeans to be processed in the South, Southeast and Northeast regions.

As for this agricultural commodity, in 2012, it represented $75.2 \%$ of the raw material used to produce biodiesel, followed by beef tallow $(17.2 \%)$, cotton $(4.5 \%)$, other fatty materials $(3 \%)$ and other raw materials $(0.1 \%)$, as Figure 7 below (MME, 2013). In 2013, in the cumulate to August, the participation of the three main raw materials was: $75.0 \%$ (soybean), $18.7 \%$ (beef fat) and 2.2\% (cotton) (MME, 2013).

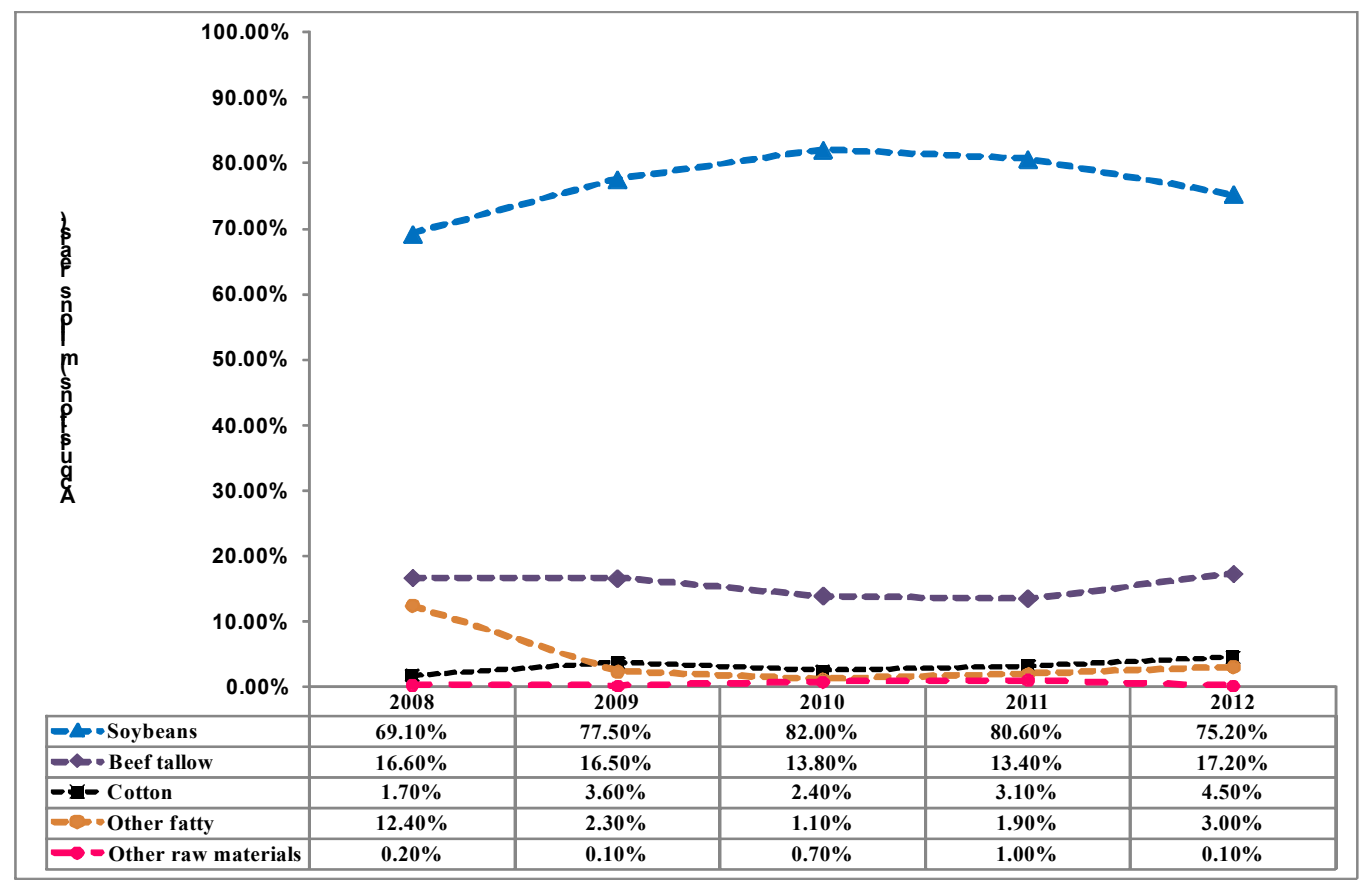

Figure 7. Main raw materials for the biodiesel production (2008 to 2012)

Source: Own elaboration from MME data (2013).

Given this situation, soybeans became a ballast supply to be considered the only oilseed serving in its entirety parameters in the program: technological field, since Brazil is one of the world leaders in the development of research and knowledge generation of this culture; efficient production scale to meet the demands required by the 
program and a wide spatial distribution of culture through all Brazilian regions (IPEA, 2010; Laviola \& Alves, 2011; Milazzo et al., 2013).

Therefore, it is concluded that the program left the main focus, which was to include underserved regions and meet the needs of family farmers and produce biodiesel with other oilseeds, castor and palm oil in particular. In other words, what was foreseen in the original PNPB is not really happening. Secondly, tax incentives adopted to attract the plants towards the Northeast and Semiarid Regions are not being effective, where those plants have been flowing into the Soybean producing States, who were not, as a priority, the target audiences and the oilseed significantly divulgated by the program.

\section{The Biodiesel Situation in the Northeast and in Bahia, Brazil}

In the present scenario, considering the nine northeastern states, only two have been producing biodiesel: Bahia and Ceará. These states accounted for about $10 \%$ of the volume of domestic production, with final data from 2012 (ANP, 2013). The Figure 8 shows the biodiesel production of the northeastern states in the period from 2005 to 2012 .

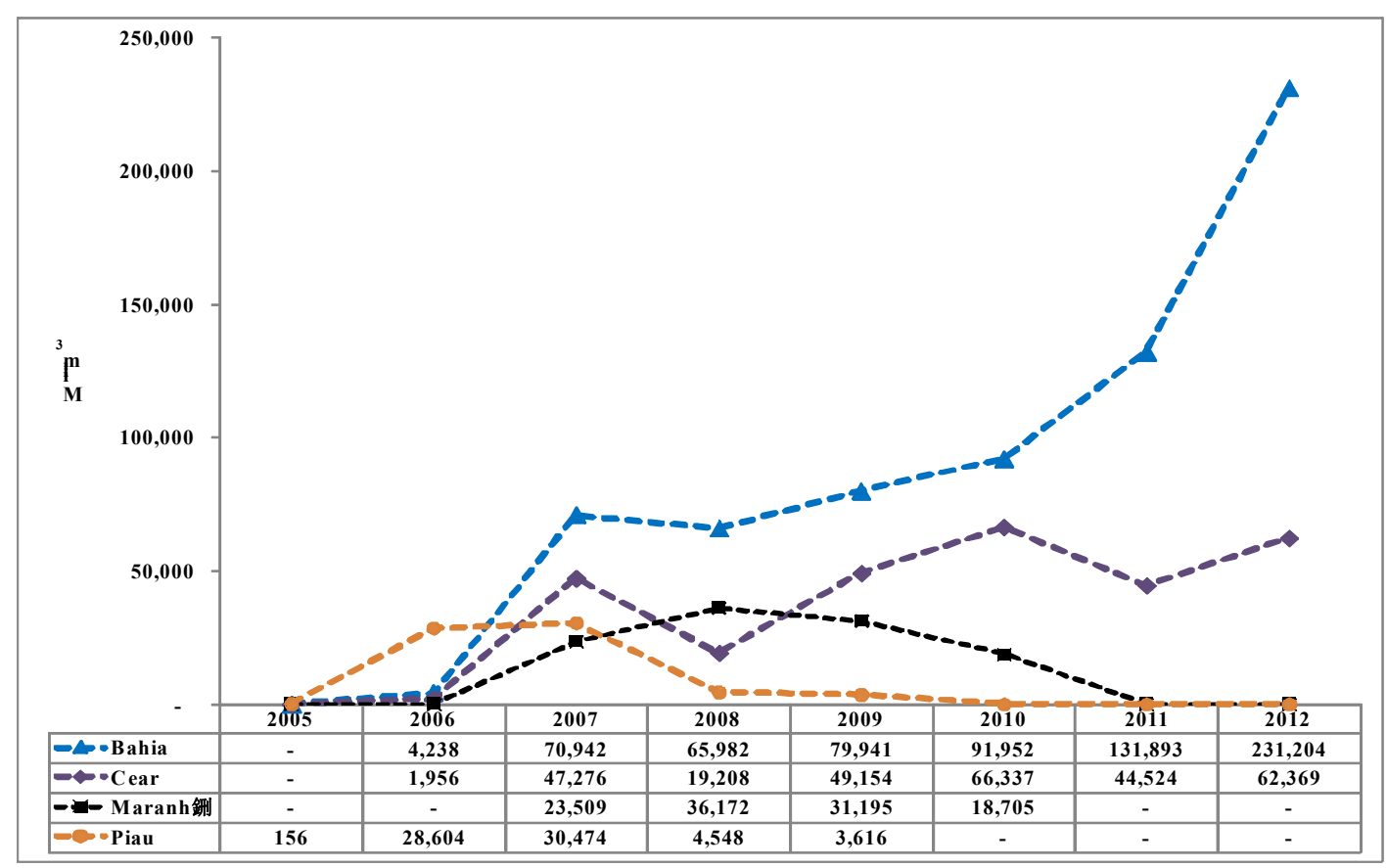

Figure 8. Biodiesel Production in the Northeast region

Source: Own elaboration from ANP data (2013).

Despite this volume, the Northeast region presented a deficit of $163,110 \mathrm{~m}^{3}$ of biodiesel to meet the mixing of $9,133,665 \mathrm{~m}^{3}$ of diesel oil consumed in the region in 2012 (ANP, 2013).

Considering the presented situation, it is a great reflection on the PNPB in the Northeast so far: Why, from the beginning of this program, the government has not given full exemption for the entire production chain of the Northeast, since the focus was to understand the most deprived regions, with emphasis on the idea of social inclusion?

Bahia has four power plants for biodiesel commercialization, for a total installed capacity of $502,7011 \mathrm{~m}^{3} / \mathrm{year}$ The Petrobras Biofuel (PBIO), located in Candeias with 217,200 $\mathrm{m}^{3}$ per year; the V-Biodiesel, located in Iraquara, with 129,600 $\mathrm{m}^{3} /$ year; the Comanche, located in Simões Filho, with 120,600 $\mathrm{m}^{3} /$ year, and the Biobrax located in Una with 35,200 $\mathrm{m}^{3} /$ year (ANP, 2013). The Biodiesel production in the state is illustrated in Table 4 below.

There has been a 7\% drop in production compared with the period 2008/2007, caused by difficulties, at the time, in the plant BrasilEcodiesel, due to the price transacted at an auction in November 2007, of R $\$ 1.86$, whereas the soybean oil, in the same period, was R\$ 2.00 per liter, derailing the production (BIODIESELBR, 2008). 
Table 4. Biodiesel Production in Bahia - B100 - 2005-2012 $\left(\mathrm{m}^{3}\right)$

\begin{tabular}{ccccccccc}
\hline Months/periods & 2005 & 2006 & 2007 & 2008 & 2009 & 2010 & 2011 & 2012 \\
\hline January & - & - & 1,669 & 10,435 & 1,880 & 6,571 & 12,095 & 17,897 \\
February & - & - & 1,549 & 6,623 & 4,043 & 9,780 & 9,395 & 17,817 \\
March & - & - & 5,814 & 7,061 & 5,703 & 11,325 & 10,679 & 15,010 \\
April & - & - & 3,140 & 4,178 & 1,790 & 9,909 & 4,869 & 14,227 \\
May & - & - & 3,913 & 1,772 & 5,617 & 10,013 & 4,975 & 19,192 \\
June & - & - & 7,328 & 2,693 & 7,641 & 7,236 & 8,912 & 19,133 \\
July & - & - & 5,658 & 1,980 & 7,651 & 2,598 & 10,038 & 22,494 \\
August & - & - & 6,585 & 3,569 & 9,100 & 7,418 & 9,102 & 22,001 \\
September & - & - & 7,632 & 7,362 & 8,932 & 10,281 & 8,364 & 19,939 \\
October & - & 9 & 8,953 & 5,777 & 9,245 & 5,858 & 17,647 & 19,714 \\
November & - & 16 & 9,166 & 7,607 & 10,173 & 6,397 & 20,190 & 20,698 \\
December & - & 4,213 & 9,534 & 6,924 & 8,166 & 4,567 & 15,626 & 23,083 \\
Total oftheyear & - & 4,238 & 70,942 & 65,982 & 79.941 & 91,952 & 131,893 & 231,204 \\
\hline
\end{tabular}

Source: Own elaboration from ANP data (2013).

In fact, the BrasilEcodiesel - Iraquara / BA, after this episode, has encountered serious economic and administrative difficulties, failing to stabilize the market and going into decline after cessation of Social Fuel Stamp in March 2010, being acquired for Vanguarda and then by Oleoplan group, being called afterwards of V-Biodiesel and then having the SFS recovered in mid-2011. It is noteworthy that, during these processes, the production stagnated for several months.

In the period from 2008 to 2010 , the state production increased by an average $21 \%$ per period, due to the entrance of the PBIO market in Bahia, despite the fluctuating delivery of the product by V-Biodiesel (ex-BrasilEcodiesel) and financial and technical difficulties of Comanche.

In the period from 2010 to 2012, the highlight was the idle capacity of the power plants installed in the state, as shown in the Table 5 below.

Table 5. Biodiesel Production of the biodiesel power plants in Bahia $\left(\mathrm{m}^{3}\right)$-from 2010 to 2012

\begin{tabular}{|c|c|c|c|c|c|c|c|c|c|}
\hline \multirow[b]{2}{*}{ Data } & \multicolumn{3}{|c|}{ Comanche } & \multicolumn{3}{|c|}{ V-Biodiesel (ex- Brasil Ecodiesel) } & \multicolumn{3}{|c|}{ Petrobras Biocombustível - PBIO } \\
\hline & 2010 & 2011 & 2012 & 2010 & 2011 & 2012 ( Note 5) & 2010 & 2011 & 2012 \\
\hline January & - & 1,700 & - & 2,381 & - & 6,039 & 4,189 & 10,396 & 11,858 \\
\hline February & - & 1,585 & - & 4,346 & - & 5,453 & 5,434 & 7,809 & 12,364 \\
\hline March & - & 49 & - & 4,825 & - & 5,192 & 6,500 & 10,630 & 9,819 \\
\hline April & 1,369 & 13 & - & 4,536 & - & 4,265 & 4,004 & 4,856 & 9,963 \\
\hline May & 1,650 & - & - & 398 & - & 6,784 & 7,964 & 4,975 & 12,408 \\
\hline June & 1,758 & - & - & - & - & 7,936 & 5,478 & 8,912 & 11,197 \\
\hline July & 128 & - & - & - & - & 6,521 & 2,469 & 10,038 & 15,973 \\
\hline August & 291 & - & - & - & - & 7,362 & 7,127 & 9,102 & 14,639 \\
\hline September & 310 & - & - & - & 390 & 7,458 & 9,971 & 7,974 & 12,481 \\
\hline October & 2,004 & - & - & - & 6,149 & 6,019 & 3,854 & 11,498 & 13,694 \\
\hline November & 2,119 & - & - & - & 6,325 & 6,821 & 4,277 & 13,865 & 13,877 \\
\hline December & 236 & - & - & - & 6,906 & 7,522 & 4,331 & 8,719 & 15,561 \\
\hline Total & 9,866 & 3,348 & - & 16,487 & 19,771 & 77,372 & 65,599 & 108,774 & 153,833 \\
\hline
\end{tabular}

Source: Own elaboration from ANP data (2013). 
The V-Biodiesel (ex-BrasilEcodiesel) registered a vacancy rate in 2010, 2011 and 2012 of $87.35 \%, 84.7 \%$ and $40.3 \%$ respectively. The Comanche did not show production in 2012 and in 2009, 2010 and 2011 there was a vacancy rate of $92.5 \%, 91.8 \%$ and $97.3 \%$ respectively.

In 2011, Biobrax was authorized to commercialize, snapping up their first batch on the 21th auction of that year. However, it could not deliver the volume fetch and the plant failed to produce any liter of biodiesel so far. It happened due to a dispute among the large power plants in biodiesel auctions and the shortage of oilseeds in the region where the plant was installed, considering that the region produces cocoa and palm oil.

To make matters worse, the Comanche plant production had been paralyzed, since April 2011, fact related to the issues of settlement of labor liabilities, salaries to employees and collaborators delayed, getting unable to produce due to financial and management difficulties, including blocking of judicial open invoices with Petrobras Distribuidora, in order to settle the labor output (BIODIESELBR, 2011).

Finally, the PBIO/Bahia presented during the period idle indexes of $69.8 \%, 50 \%$ and $29.2 \%$ in 2010,2011 and 2012 , respectively. The year of 2012 is noteworthy, in which the company produced $65.54 \%$ of the biodiesel in the state, leaving for the V-Biodiesel $34.46 \%$ of the production (ANP, 2013).

Despite the successive increases in the biodiesel production and the presented results, the National PBIO had financial losses of 577 million in the last four years, being distributed as follows: 92 million in 2009, 110 million in 2010, 157 million in 2011 , and 218 million in 2012 (PETROBRAS, 2013). It means that this PBIO also operates in the market negatively, despite its structural support in the energy sector.

The relevance of this analysis is to see the real potential and capacity of the state in the biofuel production. Bahia demanded in 2010, 2011 and 2012, approximately 2,729 million $\mathrm{m}^{3}, 2,905$ million $\mathrm{m}^{3}$ and 3,166 million $\mathrm{m}^{3}$, respectively, of diesel oil per year (ANP, 2013) and the goal established by the national program is $5 \%$ of biodiesel added to diesel since $01 / 01 / 2010$. It means that the state needs $158,300 \mathrm{~m}^{3}$ of biodiesel to respond institutionally to this program. Therefore, it can be stated that the State of Bahia in 2012 had a leftover of about $73,000 \mathrm{~m}^{3}$ and in 2010 and 2011 there was a deficit of $40,000 \mathrm{~m}^{3}$ and $5,000 \mathrm{~m}^{3}$, respectively.

Despite the positive results of 2012, considered as insignificant by the size of the state of Bahia, it is necessary to review urgently its guidelines and the diverse public policies in the area of bioenergy, in order to reverse the current scenario presented.

\section{Barriers of the PNPB in the Northeast and Bahia, Brazil}

There are several issues for the impracticability of the biodiesel production chain in the Northeast, since most of the failures pointed out mostly in the research are the public policies adopted, from the primary production to the final consumer. The comments were listed in perspective of and a macro and regional environment. The macro environment is an overview for all types of biodiesel, in other words it is related to Biodiesel Program as a whole. The regional environment corresponds to the obstacles in the sectorial or local level such as the castor biodiesel program in the state of Bahia. Therefore, any influence in the macro environment will affect any type of oilseed for the biodiesel production.

After tabulating the data, the information obtained was triangulated, enabling the understanding and explanation of the problem studied. The main obstacles of biodiesel in the Northeast were detected, especially in the state of Bahia, and according to their environments were classified into four (4) categories of analysis listed below: (I) Regulatory Barriers and Public Policies; (II) Economic Barriers; (III) Agronomic Barriers; and (IV) Technological and Infrastructural Barriers.

The Regulatory Barriers and Public Policies category examines the regulatory framework for biodiesel, as well as legal grounds related to its productive chain. The Table 6 presents a compilation of the obtained results. 
Table 6. Compilation of the obtained results in the Regulatory Barriers category

\begin{tabular}{|c|c|c|}
\hline Barriers & $\begin{array}{l}\text { Regulatory } \\
\text { Investigated } \\
\text { Elements and of } \\
\text { Public Policies }\end{array}$ & Comments \\
\hline \multirow{6}{*}{$\begin{array}{l}\text { Regulatories } \\
\text { and of Public } \\
\text { Policies }\end{array}$} & $\begin{array}{l}\text { Granting of subsidies } \\
\text { for the biodiesel chain } \\
\text {-Federal taxes } \\
\text { reduction }\end{array}$ & $\begin{array}{l}\text { Different subsidies andit does not benefitsome raw materials } \\
\text { (Eg.:animal tallow and residual oils and fats (ROF) }\end{array}$ \\
\hline & Social Fuel Stamp & $\begin{array}{l}\text { Federal and state taxation incoherent by acquire quantity of raw } \\
\text { materials. } \\
\text { Tight control in the percentage distribution by regions to plead the } \\
\text { Social Fuel Stamp, especially in the Northeast region. }\end{array}$ \\
\hline & $\begin{array}{l}\text { Auctions: Regulation } \\
\text { and Prices }\end{array}$ & $\begin{array}{l}\text { Inconsistency in the auction system. There is no standardized way of } \\
\text { auctions and prices. }\end{array}$ \\
\hline & $\begin{array}{l}\text { Social Capital of the } \\
\text { biodiesel power plant. }\end{array}$ & $\begin{array}{l}\text { The system created does not prestige the small industry; does not } \\
\text { prestige cooperatives and associations. It honors the great investor, } \\
\text { causing a concentration of the biodiesel market for large } \\
\text { corporations. }\end{array}$ \\
\hline & $\begin{array}{l}\text { Kandir Law (federal } \\
\text { law of exemption } \\
\text { from federal taxes) }\end{array}$ & $\begin{array}{l}\text { The Kandir Law, established in 1996, exempt from Tax on the } \\
\text { Operations Related to Circulation of Goods and on Provision of } \\
\text { Interstate and Inter-municipality Transportation Services and of } \\
\text { Communication(ICMS), primary, industrial semi-produced products } \\
\text { and services destined for export. }\end{array}$ \\
\hline & $\begin{array}{lr}\text { Public biodiesel } \\
\text { policies in Bahia } \\
\text { disorganized }\end{array}$ & $\begin{array}{l}\text { The State of Bahia has biodiesel programs disjointed with the } \\
\text { production chain links, with presentations of objectives, without } \\
\text { defining how to achieve the set goals. }\end{array}$ \\
\hline
\end{tabular}

Source: Survey data collected by the authors.

The Economic Barriers category seeks to relate the key macroeconomic and microeconomic difficulties related to demand, supply, price, the production, planted area, taxation and other relevant matters to this category. The Table 7 presents a compilation of the obtained results.

Table 7. Compilation of the obtained results in the Economic Barriers category

Investigated Elements
Economic Barriers

\begin{tabular}{lll}
\hline & $\begin{array}{l}\text { Each Brazilian state adopts a tactic for the ICMS, } \\
\text { presenting different ratios of the standard rate. }\end{array}$ \\
ICMS - Tax on the Operations & $\begin{array}{l}\text { The State of Bahia adopts criteria of ICMS } \\
\text { Related to Circulation of Goods } \\
\text { and on Provision of Interstate and } \\
\text { Inter-municipality Transportation } \\
\text { Services and of Communication }\end{array}$ & $\begin{array}{l}\text { Integration of the State of Bahia, which harms the } \\
\text { plants installed in the state by the criteria of } \\
\text { production, according to the supplier region. }\end{array}$ \\
& $\begin{array}{l}\text { Economic } \\
\text { Oil seeds production }\end{array}$ & $\begin{array}{l}\text { It was registered an instability in the oilseed } \\
\text { production in Bahia in recent years (2005-2012); } \\
\text { It was registered an import of raw material from } \\
\text { other Brazilian states to meet the installed industries }\end{array}$ \\
\hline
\end{tabular}


in the State of Bahia.

Installed and production capacity

Shortage of public funding for companies and producers

Oil seeds prices

Agricultural subsidies with financial incentives for planting

Fidelity

Lack of organization of the cooperatives for the biodiesel production
It was registered a high idle capacity (national and state level), related to the high capacity installed, without the availability of raw materials, thus compromising the biodiesel production.

Low level of financing for production, research and development and a lot of bureaucracy to obtain it.

Producers indebted, not entitled to funding.

Price fluctuation, due to the competition from biodiesel plants with crushing companies vegetable oils.

There are no subsidies for planting in Bahia by planted area, to purchase fertilizers and guaranteed minimum prices for all oilseeds.

There is a breach of contract made by the family farmer with the cooperative or association in the delivery of raw material.

The government does not prioritize the promotion and management of cooperatives for the biodiesel production.

Source: Survey data collected by the authors.

In the Agronomic Barriers category, several points of great agronomic importance were observed, such as: agronomic treatment, qualified seeds, technical assistance, agricultural zoning and other matters. The Table 8 presents a compilation of obtained results.

Table 8. Compilation of the obtained results in the Agronomic Barriers category

\begin{tabular}{|c|c|c|}
\hline \multicolumn{2}{|c|}{$\begin{array}{c}\text { Investigated Elements } \\
\text { AgronomicBarriers }\end{array}$} & Comments \\
\hline \multirow{7}{*}{ Agronomic } & Seeds for planting & $\begin{array}{l}\text { There is no satisfactory distribution of seeds and } \\
\text { they are not qualified and certified. }\end{array}$ \\
\hline & Distributions of pluviometric stations & Few pluviometric stations in the state of Bahia \\
\hline & Agricultural zoning & $\begin{array}{l}\text { There are some municipalities without zoning } \\
\text { due to the Northeastern states have deficiencies } \\
\text { in Pluviometric Stations. }\end{array}$ \\
\hline & Agronomic treats & $\begin{array}{l}\text { Difficulties in basic inputs for planting, } \\
\text { harvesting and handling. }\end{array}$ \\
\hline & Productivity & $\begin{array}{l}\text { It was registered a low productivity per hectare of } \\
\text { castor and palm oil in the Northeast and in Bahia. }\end{array}$ \\
\hline & Lack of preparation / training of farmers & $\begin{array}{l}\text { There is no specific field of work to prepare } \\
\text { farmers, enabling and training them efficiently } \\
\text { and effectively. }\end{array}$ \\
\hline & $\begin{array}{l}\text { Precarious Technical Assistance precarious by } \\
\text { the cooperatives contracted by the biodiesel } \\
\text { power plants }\end{array}$ & $\begin{array}{l}\text { It was registered, from the cooperatives } \\
\text { contracted, low hiring technicians and } \\
\text { agronomists. }\end{array}$ \\
\hline
\end{tabular}

Source: Survey data collected by the authors. 
Finally, in, are highlighted the main points about logistics, training and qualification courses, government actions to promote the attraction of companies related to the field, research and development, among others. The Table 9 presents a compilation of the obtained results.

Table 9. Compilation of the obtained results in the Technological and Infrastructural Barriers category

\begin{tabular}{|c|c|c|}
\hline & $\begin{array}{c}\text { Investigated Elements } \\
\text { Technological and Infrastructural Barriers }\end{array}$ & Comments \\
\hline \multirow{6}{*}{$\begin{array}{l}\text { Infrastruture and } \\
\text { Technological }\end{array}$} & $\begin{array}{l}\text { Logistics for the distribution of seeds } \\
\text { (grains) }\end{array}$ & $\begin{array}{l}\text { It lacks information about the schedule of } \\
\text { cities that will be favored by the distribution } \\
\text { of seeds (grains). }\end{array}$ \\
\hline & Impact of road conditions & $\begin{array}{l}\text { The conditions of the roads bring impacts on } \\
\text { fixed freight costs and the variable costs of } \\
\text { the product. }\end{array}$ \\
\hline & $\begin{array}{l}\text { Government of Bahia actions-biodiesel } \\
\text { group }\end{array}$ & $\begin{array}{l}\text { It was registered a mismatch between the } \\
\text { secretariats government of Bahia in } \\
\text { structuring the productive chain. }\end{array}$ \\
\hline & $\begin{array}{l}\text { Continued investment in research in the State } \\
\text { of Bahia }\end{array}$ & $\begin{array}{l}\text { It was registered a discontinuity of the } \\
\text { research project on biodiesel in some } \\
\text { institutions operating in the state. }\end{array}$ \\
\hline & $\begin{array}{l}\text { Shortage of technical courses in the area of } \\
\text { biodiesel, under graduation, specialization, } \\
\text { master's and doctorate in specific area }\end{array}$ & $\begin{array}{l}\text { There was no planning and priority to settle } \\
\text { up courses in biofuels, biodiesel or } \\
\text { renewable energies in Educational } \\
\text { Institutions in Bahia. }\end{array}$ \\
\hline & Research and Development & $\begin{array}{l}\text { It was registered a shortage of research and } \\
\text { development in various areas. }\end{array}$ \\
\hline
\end{tabular}

Source: Survey data collected by the authors

According to the elements investigated, it was found in the research that the regulatory framework is one of the main tools that have hampered the entire production process from the producer to the consumer of biofuels, also to the strengthening of productive agents in the Northeast region.

From the standpoint of public policies of the State of Bahia for the biodiesel industry, it was realized that no program has a well-defined strategic planning with actions, goals and resources for the installation of new power plants, research, distribution of supplies, technical assistance, rural capacity, infrastructure, among others.

Regarding the research data, the major economic barrier is guided by the supply and demand of raw materials for biodiesel production, without taking into account other existing economic elements that have hindered the growth of biodiesel production in the Northeast and in Bahia.

Several considerations have been raised about the agronomic barriers, and it was found the great importance of carrying out agricultural researches, the provision of technical assistance and especially the inclusion of new agricultural technologies. The moment requires concentrated effort to offer real solutions to the biodiesel agribusiness, mainly in the region and the state researched.

The real solutions to the technological and infrastructural difficulties described in the research were put into question, for the purpose of execution of base works for the flow of production, to provide input to the research and development, among others.

\section{Conclusions}

In order to answer the purpose of the research, the results of the analysis will be explained.

There is no doubt that biodiesel is a worldwide option to generate more sustainable energy. Beyond the environmental run, the production of this fuel from different oilseeds implies the need to expand the agricultural production and major potential crops to meet this new market. 
From the point of view of sustainability of the PNPB market, there are guidelines that are commendable, including the biodiesel production through a variety of raw materials, from an increased participation of cooperatives located in the regional poles and the attempt to promote the inclusion of family farmers in the biodiesel production chain, especially in the North and Northeast regions of Brazil. However, the biodiesel market in the Northeast, and in particular the state of Bahia, ran into a huge idle capacity found in its industrial park, a high market concentration, a low production of biodiesel in the Northeast due to the amount of power plants installed in this region, as well as an unavailability of raw materials to meet the firms operating in this region.

The family farming was included to the PNPB in order to fully meet the secular appeal of this segment. However, despite its inclusion in the official biodiesel program, it actually is not included in positive numbers.

The truth is that some family farmers were able to take advantages with the input of biodiesel in several production arrangements of the PNPB, due to certain changes in the price of oilseeds, because of the entry of this biofuel in the fuel market in Brazil.

However, this increase in price could not make the income of farmers to be increased proportionately. Secondly, the family farmers who have benefited in some way with the production of raw materials for the PNPB were soybean producers in the South and Midwest regions, according to the presented data about the acquisition of raw materials for production. Finally, it was noted that cooperatives are concentrated in soybean producing regions in the North and Northeast and these numbers are quite unsatisfactory, regarding the amount of farmers versus number of cooperatives.

With regard to the obstacles, it is possible to ensure that they are many, including regulatory, agronomic, economic, technological and infrastructural obstacles. Thus, exemplifying: inconsistent federal and state taxes for the biodiesel market, the lack of standardization to commercialize biodiesel in auctions, low level of financing for production, research and development, lack of subsidies for planting by planted area in Bahia, for acquisition of fertilizes, lack of satisfactory distribution of certified seeds, low productivity of oilseeds per hectare, the poor condition of the logistics flow, shortage of research and development in several fields, among others.

In practice, it is almost impossible for companies interested in producing biodiesel to enter in the Northeast market to be competitive within these scenarios of economic, technological, agronomic and regulatory uncertainties.

Therefore, the sustainability of the PNPB in the Northeast region and in the State of Bahia is questionable, due to there is no point creating the regulatory mechanisms if what actually regulates the production and the consumption is the price, especially if it is a commodity (Note 6) being negotiated in the spot (Note 7) market .

Determining prices of biodiesel and raw materials is also going against the own competitive market, which would not be rational. "Availability and consumer demand are the factors that determine the parameters of the possible or impossible" (Silva, 2008).

Since the research is deep and specialized in several areas of knowledge, it was noted that there are other barriers, as well as other elements that should be examined in future researches.

\section{Acknowledgements}

The authors thank Coordenação de Aperfeiçoamento de Pessoal de Ensino Superior (CAPES) for providing a research grant. The authors would like to acknowledge the support of Federal University of Bahia (UFBA) and Federal Institute of Bahia (IFBA).

\section{References}

Abramovay, R., \& Magalhães, R. (2007). O acesso dos agricultores familiares aos mercados de biodiesel: parcerias entre grandes empresas e movimentos sociais. Textos para discussão, n. 6, FIPE. Retrieved from http://www.fipe.org.br/web/publicacoes/discussao/textos/texto_06_2007.pdf

Altafin, I. (2012). Reflexões sobre o conceito de agricultura familiar. Retrieved from http://redeagroecologia.cnptia.embrapa.br/biblioteca/agricultura-familiar/CONCEITO\%20DE\%20AGRICU LTURA\%20FAM.pdf

ANP-Agência Nacional de Petróleo, Gás Natural e Biocombustíveis. (2013). Boletim mensal de biodiesel. Janeiro de 2013. Retrieved from http://www.anp.gov.br

ANP-Agência Nacional de Petróleo, Gás Natural e Biocombustíveis. (2013). Dados estatísticos mensais. 2013. Retrieved from http://www.anp. gov.br 
Bergmann, J. C., Tupinambá, D. D., Costa, O., Almeida, J. R. M., Barreto, C. C., \& Quirino, B. F. (2013). Biodiesel production in Brazil and alternative biomass feedstocks. Renewable and Sustainable Energy Reviews, 21, 411-420. http://dx.doi.org/10.1016/j.rser.2012.12.058

Biodieselbr. (2008). MDA admite preocupação com Brasil Ecodiesel. Retrieved from http://www.biodieselbr.com/noticias/bio/mda-preocupacao-brasil-ecodiesel-23-06-08.htm

Biodieselbr. (2011). Justiça bloqueia $R \$ 350$ mil da Comanche. Retrieved from $\mathrm{http}$ ://www.biodieselbr.com/noticias/em-foco/justica-bloqueia-r350-mil-comanche-300811.htm

Brasil. Casa Civil. (2005). Lei $n^{\circ}$. 11.097, de 13 de janeiro de 2005. Dispõe sobre a introdução do biodiesel na matriz energética brasileira; altera as Leis nos 9.478, de 6 de agosto de 1997, 9.847, de 26 de outubro de 1999 e 10.636, de 30 de dezembro de 2002; e dá outras providências. Retrieved from http://www.planalto.gov.br/ccivil_03/_ato2004-2006/2005/Lei/L11097.htm

Brasil. Casa Civil. (2006). Lei $n^{o}$. 11.326, de 24 de julho de 2006. Estabelece as diretrizes para a formulação da Política Nacional da Agricultura Familiar e Empreendimentos Familiares Rurais. Retrieved from http://www.planalto.gov.br/ccivil_03/_ato2004-2006/2006/lei/111326.htm

Brasil. Presidência da República. (2004). Decreto $n^{\circ} .5 .297$ de 06 de dezembro de 2004. Dispõe sobre os coeficientes de redução das alíquotas da Contribuição para o PIS/Pasep e da Cofins incidentes na produção e na comercialização de biodiesel, sobre os termos e as condições para a utilização das alíquotas diferenciadas, e dá outras providências. Retrieved from http://www.mda.gov.br/portal/saf/programas/biodiesel/2290882

Buainain, A. M., Guanziroli, C. E., \& Sabbato, A. D. (2004). Agricultura familiar: um estudo de focalização regional. In: Congresso da Sociedade Brasileira de Economia e Sociologia Rural, Cuiabá. Anais eletrônicos... Cuiabá: SOBER. Retrieved from http://www.sober.org.br/palestra/12/09O437.pdf

Castro, C. N. (2011). O Programa Nacional de Produção e Uso do Biodiesel (PNPB) e a produção de matéria-prima de óleo vegetal no Norte e no Nordeste. Brasil, Rio de Janeiro: IPEA

César, A. S., \& Batalha, M. O. (2013). Brazilian biodiesel: The case of the palm's social projects. Energy Policy, 56, 165-174. http://dx.doi.org/10.1016/j.enpol.2012.12.014

César, A. S., Batalha, M. O., \& Zopelari, A. L. M. (2013). Oil palm biodiesel: Brazil's main challenges. Energy, 60, 485-491. http://dx.doi.org/10.1016/j.energy.2013.08.014

Dermibas, A. (2009). Progress and recent trends in biodiesel fuels. Energy Conversion and Management, 50, 14-34. http://dx.doi.org/10.1016/j.enconman.2008.09.001

Diniz, J. F., \& Favareto, A. (2012). Os desafios da inclusão da agricultura familiar no mercado de matéria-prima para o biodiesel no Brasil. Estudos Sociedade e Agricultura, 20, 139-187. Retrieved from http://r1.ufrrj.br/esa/V2/ojs/index.php/esa/article/view/351

EMBRAPA (2013). Agricultura. Retrieved from https://www.embrapa.br/

FGV-Fundação Getúlio Vargas. (2013). Análise do Impacto na Inflação do Aumento da Mistura de Biodiesel no Diesel. Relatório Final. Rio de Fevereiro: Fundação Getúlio Vargas.

França, C. G., Del Grossi, M. E., \& Marques, V. P. M. A. (2009). O censo agropecuário 2006 e a agricultura familiar no Brasil. Brasília: Ministério do Desenvolvimento Agrário.

Gil, A. C. (2009). Métodos e técnicas de pesquisa social. São Paulo: Atlas.

Goldemberg, J., Schaeffer, R., Szklo, A., \& Lucckesi, R. (2014). Oil and natural gas prospects in South America: Can the petroleum industry pave the way for renewables in Brazil? Energy Policy, 64, 58-70. http://dx.doi.org/10.1016/j.enpol.2013.05.064

Goncalves, Y. K., Favareto, A., \& Abramovay, R. (2013). Estruturas sociais no semiárido e o mercado de biodiesel. 2013. Cad. CRH 26, 68, 347-362. http://dx.doi.org/10.1590/S0103-49792013000200009

GREENPEACE. (2010). [R]evolução Energética: a caminho do desenvolvimento limpo. Retrieved from http://www.greenpeace.org/brasil/Global/brasil/report/2010/11/revolucaoenergeticadeslimpo.PDF

Hertel, T., \& Tyner, W. E. (2013). Market-mediated environmental impacts of biofuels. 2013. Global Food Security, 2, 131-137. http://dx.doi.org/10.1016/j.gfs.2013.05.003

IBGE-Instituto Brasileiro de Geografia e Estatística. (2010). Censo Agropecuário de 2006. Rio de Janeiro: IBGE. Retrieved from http://www.ibge.gov.br 
IEA-Internation Energy Agency. (2012). World Energy Outlook 2012. Retrieved from http://www.worldenergyoutlook.org/ publications/weo-2012/

IPEA-Instituto de Pesquisa de Economia Aplicada. (2010). Biocombustíveis no Brasil: Etanol e Biodiesel. Comunicados do IPEA, n53, Secretaria de Assuntos Estratégicos daPresidência da República: Brasília. Retrieved from http://www.ipea.gov.br

IPEA-Instituto de Pesquisa de Economia Aplicada. (2012). Biodiesel no Brasil: desafios das políticas públicas para a dinamização da produção. Comunicados do IPEA $\mathrm{n}^{0}$ 137, Brasília: Secretaria de Assuntos Estratégicos da Presidência da República. Retrieved from http://www.ipea.gov.br

Lamarche, H. (1993). A agricultura familiar: comparação internacional - uma realidade multiforme. Coleção Repertórios Campinas: UNICAMP.

Laviola, B. G., \& Alves, A. A. (2011). Novas e boas fontes para a produção de biodiesel. Anuário de Energias Renováveis. São Paulo: Informa Economics FNP.

Leite, J. G. D. B., Bijman, J., Giller, K., \& Slingerland. M. (2013). Biodiesel policy for family farms in Brazil: One-size-fits-all? Environmental Science \& $\quad$ Policy, $\quad 27, \quad$ 195-205. http://dx.doi.org/10.1016/j.envsci.2013.01.004

Machado, A. G. (2012). As Ações e Estratégias do Governo para o Selo Social. In: Congresso Agribio: Agricultura Familiar no Biodiesel. $\quad$ Retrieved from http:/www.biodieselbr.com/noticias/agricultura/selo/acoes-estrategias-selo-social-andre-machado-agribio-1 20712.htm

Marconi, M. de A., \& Lakatos, E. M. (2008). Técnicas de pesquisa: planejamento e execução de pesquisas, amostragens e técnicas de pesquisa, elaboração, análise e interpretação de dados. São Paulo: Atlas.

MCT-Ministério de Ciência e Tecnológia. (2005). O Programa Nacional de Produção e Uso de Biodiesel - PNPB. Brasília, DF: MCT. Retrieved from http://www.biodiesel.gov.br

MDA-Ministério do Desenvolvimento Agrário. (2008). Descrição do Projeto Polos de Biodiesel. Brasília. DF: MCT. Retrieved from http://www.mda.gov.br

MDA-Ministério do Desenvolvimento Agrário. (2011). Programa Nacional de Produção e Uso de Biodiesel: inclusão social e desenvolvimento territorial. Brasília, DF: MDA. Retrieved from http://www.mda.gov.br

MDA-Ministério do Desenvolvimento Agrário. (2013). Participação da Agricultura Familiar no Brasil. 2013. GBEP - $\quad$ Global Bioenergy Partnership. Retrieved from http:/www.globalbioenergy.org/events1/gbep-events-2013/working-group-on-capacity-building-meetings2013/en/

Milazzo, M. F., Spina, F., Primerano, P., \& Bart, J. C. J. (2013). Soy biodiesel pathways: Global prospects. Renewable and Sustainable Energy Reviews, 26, 579-624. http://dx.doi.org/10.1016/j.rser.2013.05.056

MME-Ministério de Minas e Energia. (2013). Boletim mensal dos combustíveis Renováveis. Brasília, MME/SPG, n. 61. Retrieved from http://www.mme.gov.br/spg/menu/ publicacoes.html

Nogueira, L. A. H. (2011). Does biodiesel make sense? Energy, 36, 3659-3666. http://dx.doi.org/10.1016/j.energy.2010.08.035

Padula, A. D., Santos, M. S., Ferreira, L., \& Borenstein, D. (2012). The emergence of the biodiesel industry in Brazil: Current figures and future prospects. Energy Policy, 44, 395-405. http://dx.doi.org/10.1016/j.enpol.2012.02.003

Pereira, M. G., Camacho, C. F., Freitas, M. A. V., \& Silva, N. F. (2012). The renewable energy market in Brazil: Current status and potential. Renewable and Sustainable Energy Reviews, 16, 3786-3802. http://dx.doi.org/10.1016/j.rser.2012.03.024

Perez, R. (2012). Os desafios do Selo Social no Norte e Nordeste. In: Congresso Agribio: Agricultura Familiar no Biodiesel.

Retrieved

from http://www.biodieselbr.com/noticias/agricultura/selo/dificuldades-selo-social-norte-nordeste-perez-240712. htm

PETROBRAS. (2013). Relatório de atividade/2012. $\quad$ Retrieved from http://www.investidorpetrobras.com.br/pt/central-de-resultados/ 
Quintella, C. M., Teixiera, L. S. G., Korn, M. G. A., Costa Neto, P. R., Torres, E. A, Castro, M. P., \& Jesus, C. A. C. (2009). Cadeia do biodiesel da bancada à indústria: uma visão geral com prospecção de tarefas e $\begin{array}{lllll}\text { oportunidades Para } & \text { P\&D\&I. } & \text { Novara } & 32,808 .\end{array}$ http://dx.doi.org/10.1590/S0100-40422009000300022

REN-Renewable Energy Policy Network. (2013). Renewables 2013 Global Status Report. Paris: REN21 Secretariat, 2013. Retrieved from http://www.ren21.net

Repórter Brasil. (2012). A agricultura familiar e o programa nacional de biodiesel: retrato do presente, perspectivas de futuro. Retrieved from http://www.reporterbrasil.org.br/documentos/AgriculturaFamiliar_Biodiesel2010.pdf

Rodrigues, R. A. (2012). Desenvolvendo o Novo Marco Regulatório do Biodiesel. In: Conferência Internacional Biodieselbr. Retrieved from http:/www.biodiesels.com.br/wp-content/uploads/2013/04/Rodrigo_Rodrigues-Casa-Civil.pdf

Rovere, E. L. L., Pereira, A. S., \& Simões, A. F. (2011). Biofuels and Sustainable Energy Development in Brazil. World Development, 39, 1026-1036. http://dx.doi.org/10.1016/j.worlddev.2010.01.004

Santos, O. I. B., \& Rathmann, R. (2009). Identification and analysis of local and regional impacts from the introduction of biodiesel production in the state of Piauí. Energy Policy, 37, 4011-4020. http://dx.doi.org/10.1016/j.enpol.2009.05.002

Silva Junior, Daniel. (2013). Impacts of biodiesel on the Brazilian fuel market. Energy Economics, 36, 666-675. http://dx.doi.org/10.1016/j.eneco.2012.11.008

Silva, M. S. (2008). Biodiesel no Estado da Bahia: potencialidades, entraves e ações indutoras. Dissertação (Mestrado) - Departamento de Engenharia, Universidade Salvador - UNIFACS. Mestrado em Regulação da $\begin{array}{lllll}\text { Indústria } & \text { de } & \text { Snergia, } & \text { Retrieved }\end{array}$ http://tede.unifacs.br/tde_busca/arquivo.php?codArquivo $=320$

Távora, Fernando Lagares. (2012). Biodiesel e Proposta de um novo Marco Regulatório: Obstáculos e Desafios. Núcleo de Estudos e Pesquisas do Senado Federal: Brasília. Textos para discussão no 116.

Torres, E. A., Chirinos, H. D., Alves, C. T., Santos, D. C., \& Camelier, L. A. (2006). Biodiesel: o novo combustível para o novo século. Bahia Análise \& Dados, 16, 89-95.

UN-United Nations. (2011). World Population Prospects: The 2010 Revision, Highlights And Advance Tables. New York: United Nations. Retrieved from http://Esa.Un.Org/Wpp/Documentation/Pdf/Wpp2010_Highlights.Pdf>

Vaccaro, G. L. R., Pohlmann, C., Lima, A. C., Santos, M. S., Souza, C. B., \& Azevedo, D. (2010). Prospectives cenarios for the biodiesel chain of a Brazilian state. Renewable and Sustainable Energy Reviews, 14, 1263-1272. http://dx.doi.org/10.1016/j.rser.2009.12.008

Watanabe, K., Bijman, J., \& Slingerland, M. (2012). Institutional arrangements in the emerging biodiesel industry: Case studies from Minas Gerais, Brazil. Energy Policy, 40, 381-389. http://dx.doi.org/10.1016/j.enpol.2011.10.023

Wilkinson, J., \& Herrera, S. (2010). Biofuels in Brazil: debates and impacts. The Journal of Peasant Studies, 3, 749-768. http://dx.doi.org/10.1080/03066150.2010.512457

\section{Notes}

Note 1 . The fiscal module is a size parameter to classify rural properties, in the formof the Law number 8.629 , of February 25, 1993.

Note 2. The Gross Value of Production (GVP) is a sum of the harvested production of all animal and plant products. This indicator represents an estimative of income generation in rural areas.

Note 3. Identification established by MDA, through Decree 5.297 de 06/12/2004 which aims to facilitate the social strategy of PNPB: inclusion of the family farmers in the biodiesel productive. With the SFS, the biodiesel producer can take advantage of reduced rates of de PIS/PASEP and COFINS.

Note 4. It refers to September, 2013.

Note 5. Until March 2012, the production is linked to BrasilEcodieselIraquara, which by that time was acquired by Vanguard and from April 2012, it is registered with V-biodiesel, now belonging to Oleoplan group. 
Note 6. This term indicates, especially in international trade relations, a specific type of unprocessed goodor primary product of commercial importance.

Note 7. The term "spot" is used on commodity exchanges to refer to business transacted with cash payment and prompt delivery of the goods, as opposed to the futures market and forward. The delivery here does not mean physical delivery, but the delivery of a certain amount of money corresponding to the amount of goods traded. An example of spot market is the market (castor oil, cotton) from the port of Rotterdam.

\section{Copyrights}

Copyright for this article is retained by the author(s), with first publication rights granted to the journal.

This is an open-access article distributed under the terms and conditions of the Creative Commons Attribution license (http://creativecommons.org/licenses/by/3.0/). 